\title{
Numerical simulation of the inelastic behavior of a structurally graded material
}

\author{
A. V. Orlov ${ }^{1}$, V.S. Sufiiarov ${ }^{1}$, E. V. Borisov ${ }^{1}$, I. A. Polozov ${ }^{1}$, D. V. Masaylo ${ }^{1}$, A. A. Popovich ${ }^{1}$, \\ M. O. Chukovenkova ${ }^{\dagger, 2}$, A. V. Soklakov², D. S. Mikhaluk ${ }^{2}$ \\ ${ }^{\dagger}$ maria.chukovenkova@multiphysics.ru
}

${ }^{1}$ Peter the Great St. Petersburg Polytechnic University, 29 Polytechnicheskaya St., St. Petersburg, 19525, Russia ${ }_{2}^{2}$ JSC “Center of Engineering Physics Simulation and Analysis”, 15 Kondratiyevskiy Av., bld. 2,

St. Petersburg, 195197, Russia

Additive manufacturing is considered to be a very promising technology when it comes to the manufacture of metal products of a complex shape for various applications, since it provides designs with improved mechanical properties. Another advantage of modern solutions for additive manufacturing is that they help manufacturers to control the in-process structure formation of final products. Of special interest is the feasibility of simultaneously creating local regions with preferred microstructures and properties. This paper discusses the effect of the process parameters of selective laser melting (SLM) on the structure and properties of Inconel 718 specimens. The results of uniaxial tension experiments on homogeneous specimens, as well as on structurally graded specimens with equiaxed fine grains and elongated coarse grains, are presented. The authors also proposed a finite-element approach to modeling of mechanical properties. The input data include experimental data describing tensile specimens manufactured using two different process regimes of SLM to obtain different types of microstructure (equiaxed fine-grained and coarse columnar-grained), as well as experimental data on tensile tests of the composite specimen. The proposed approach defines the spatial distribution of material properties in homogeneous and structurally graded specimens. This paper presents the results of modeling based on the proposed approach for the inelastic behavior of structurally graded specimens as compared to the experimental data.

Keywords: additive manufacturing, functionally graded material (FGM), finite element methods, Inconel 718.

УДК: 939.3, 621.762

\section{Численное моделирование неупругого поведения структурно-градиентного материала}

\author{
Орлов А. В. ${ }^{1}$, Суфияров В. Ш. ${ }^{1}$, Борисов Е. В. ${ }^{1}$, Полозов И. А. ${ }^{1}$, Масайло Д. В. ${ }^{1}$, \\ Попович А. А. ${ }^{1}$, Чуковенкова М. О. ${ }^{\dagger}$, , Соклаков А. В. ${ }^{2}$, Михалюк Д. С. ${ }^{2}$ \\ †maria.chukovenkova@multiphysics.ru \\ ${ }^{1}$ Санкт-Петербургский политехнический университет Петра Великого, ул. Политехническая 29, \\ С.-Петербург, 19525, Россия \\ ${ }^{2} \mathrm{AO}$ «Центр инженерно-физических расчетов и анализа», пр-т. Кондратьевский 15, корп. 2, \\ С.-Петербург, 195197, Россия
}

Аддитивное производство является перспективной отраслью, позволяющей создавать конструкции сложной формы с улучшенными механическими характеристиками. Еще одним преимуществом аддитивных технологий является управление структурообразованием в изделиях в процессе производства. Особый интерес представляет возможность одновременного создания в изделии локальных участков с заданными микроструктурой и свойствами. В данной работе проведено исследование, в результате которого определено влияние 
технологических параметров процесса селективного лазерного плавления (СЛП) на структуру и свойства образцов, выполненных из сплава Inconel 718. В работе приведены результаты экспериментов по одноосному растяжению однородных образцов, а также образцов с переменной структурой, в которых присутствуют области с мелкодисперсными равноосными зернами и крупными вытянутыми зернами. Также авторами предложен подход к численному моделированию механических характеристик, основанный на методе конечных элементов. В качестве исходных данных использованы экспериментальные данные, которые были получены в результате эксперимента по растяжению образцов, изготовленных при двух различных технологических режимах СЛП, формирующих разный тип микроструктуры (равноосную мелкодисперсную и крупнозеренную столбчатую направленную микроструктуру, соответственно), а также экспериментальные данные по растяжению составного образца. Предложенный подход позволяет задать пространственное распределение свойств материала в однородных образцах и образцах с переменной структурой. Приведены результаты моделирования неупругого поведения образцов с переменной структурой, полученные в результате применения данного подхода, и произведено сравнение с экспериментальными данными.

Ключевые слова: аддитивные технологии, функционально-градиентный материал (ФГМ), метод конечных элементов, Inconel 718.

\section{Introduction}

Additive technology is considered to be one of the most promising ways of manufacturing metal parts $[1,3]$. The selective laser melting (SLM) technology is already in active use for metal production, ensuring the manufacture of parts with precise geometry. The resulting design is adjusted for operating loads and is characterized by a minimum weight. The latter is especially relevant for such industries as aerospace and medicine [4-7]. The aircraft industry, where titanium and nickel alloys are widely used, imposes specific requirements to the weight of products [4].

Traditionally, Inconel 718 alloy is used to manufacture gas turbine components, parts of aerospace vehicles, petrochemical and nuclear structures by forging, rolling and casting, due to its heat resistance, corrosion resistance and high-temperature properties $[7,8]$. However, modern industry requires complex-shape products with high precision and improved mechanical properties, which are often impossible to achieve using traditional techniques.

The authors conducted a series of analyses of Inconel 718 produced by SLM, including the analysis of the properties of the initial powder material, the microstructure and the properties of compact specimens [9], as well as the effect of the thickness of the powder layer on the microstructural and mechanical properties of the alloy [10]. Based on the determined material behavior, the concept of microstructure control for obtaining equiaxed fine-grained and elongated coarse-grained regions was formulated [11]. However, the behavior of gradedstructure parts in the finished product is still to be studied using new approaches and techniques of modeling and analysis. Today, the design of parts, solutions and materials can hardly be developed without numerical modeling. The development of new production techniques also requires new methods of engineering analysis. When adopting new approaches, it is critical to have a predictive modeling tool for the qualitative and quantitative description of the technology and processes that are being developed.

Various approaches of the finite element method (FEM) are often used to analyze structures made of functionally graded materials (FGM) [11-13]. FGM structural optimization using FEM for specific applications requires solving a large number of direct issues. The main issue of using FEM for FGM modeling is associated with consideration of spatially varying material properties in the model. The simplest way to model the inhomogeneity of a graded material is to assign various material properties to successive layers of a finite element mesh. Such models were used by a number of researchers, for example, in [14-15]. However, this approach requires a fine mesh to achieve appropriate accuracy, which results in costly calculations, especially when it comes to the real parts of complex geometry. Further, preprocessing and mesh adaption for different graded regions is quite a timeconsuming process.

Therefore, the purpose of this paper is to determine the stress-strain behavior and mechanical properties of specimens with a graded-structure and to develop a FEM approach to the numerical modeling of the mechanical properties of FGM for the qualitative and quantitative predictive analysis of complex composites based on the behavior of the constituent materials.

\section{Methods and materials}

Compact tension specimens were made on the SLM280HL selective laser melting machine manufactured by SLM Solutions $\mathrm{GmbH}$. The initial material is a heat-resistant nickel-based alloy Inconel 718 in the form of a gas-atomized powder.

Analysis of the microstructural morphology and texture of the compact tension specimens using the electron backscatter diffraction (EBSD) method was performed in a TESCAN Mira 3 LMU scanning electron microscope (SEM), operating at a magnification of 4-106, an accelerating voltage of $200 \mathrm{~V}-30 \mathrm{kV}$. The EBSD analysis was performed at an accelerating voltage of $20 \mathrm{kV}$ with $5 \mu \mathrm{m}$ increments.

Mechanical properties were measured in accordance with ISO 6892-1 on a Zwick/Roell Z100 testing machine (Germany) with a maximum testing force of $99640 \mathrm{~N}$.

ANSYS 19, the software for the finite element analysis is used to perform the numerical analysis. Modeling was made using the CAD program module ANSYS SpaceClaim. A finite element mesh was generated using ANSYS Meshing. 
The setup, solution and post-processing of the problem were performed using ANSYS Mechanical.

The input data are the results of the experiments [1] the dependence of the strength in the specimen on the elongation. The material model is a bilinear isotropic hardening elastoplastic model. Constants required for this model are Young's modulus $E$, Poisson's ratio $\mu$, yield strength $\sigma_{0.2}$, tangent modulus $E_{t}$.

To solve the problem using the finite element method, the equation is solved as follows: $[K]\{u\}=\{F\}$, where $[K]-$ is the global stiffness matrix, $\{u\}-$ is the nodal displacement vector, $\{F\}-$ is the external force vector.

As we consider the post-yield behavior of the specimens and apply a nonlinear elastoplastic material model, we use the Newton-Raphson method for numerical solution at each step [17]. This method is an iterative process for solving a system of nonlinear equations.

The finite element model is shown in Fig. 1. The size of a final element in the model is assumed equal to $0.5 \mathrm{~mm}$, the number of nodes is 13265 . The type of the finite element used is SOLID186 (3D, 20-node). One end of the specimen is rigidly fixed, while a displacement is applied to the other end.

The input data are experimental [1], describing tensile specimens manufactured using two different regimes of the SLM process to obtain different types of microstructure, hereinafter referred to as $\mathrm{A}$ and $\mathrm{B}$ : equated fine-grained and coarse columnar-grained microstructure, respectively (for more details on the manufacturing conditions and the microstructure analysis refer to [1]). We also considered the experimental data on the tension of a composite made of the two materials: the main matrix of material $A$ and two inserts of material B (5 specimens), hereinafter referred to as $\mathrm{A}+\mathrm{B}$ (Fig. 2).

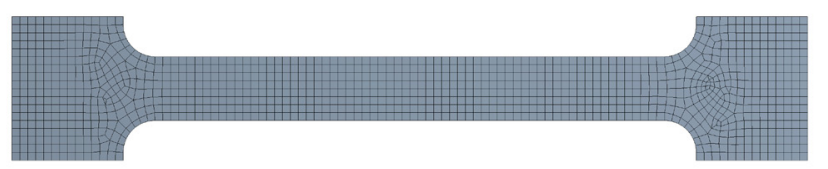

Fig. 1. Finite element model of the specimen.

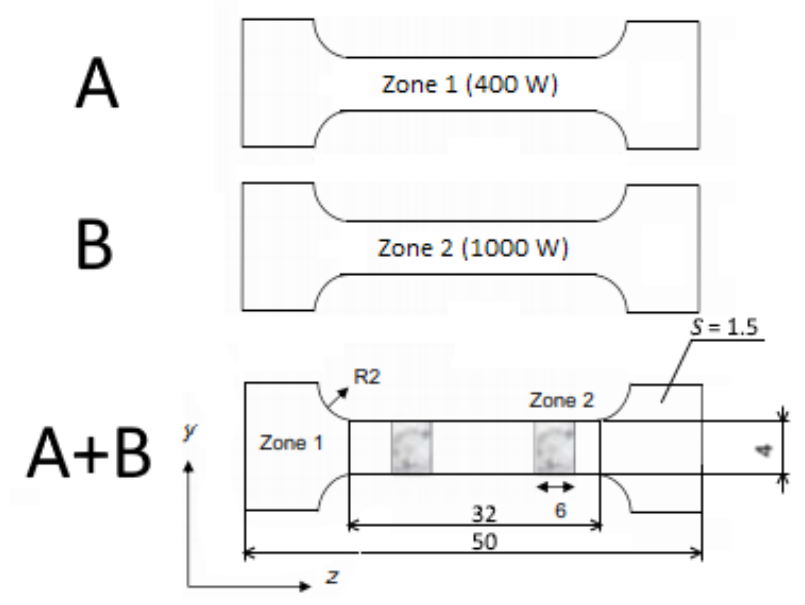

Fig. 2. Specimens A, B, A+B.

\section{Results and discussion}

Due to the rapid solidification in the SLM process $(104-106 \mathrm{~K} / \mathrm{s})$, the initial microstructure has a cellulardendritic morphology. The rate of solidification and, consequently, the cell size depend on the layer thickness and process parameters used in SLM.

Measurements showed that the average cell size in specimen $A$ is $0.9-1.1 \mu \mathrm{m}$, and in specimen B it is $1.3-2 \mu \mathrm{m}$. Other microstructural differences at different layer thicknesses are shown in Fig. 3 demonstrating the ESBD texture characterization.

The microstructure of specimen A has fine grains without preferred orientation, while the microstructure of specimen $\mathrm{B}$ has coarse elongated columnar grains with preferred orientation $<001>$.

Microstructural differences also have effects on strength properties. Specimens for tensile testing were manufactured in accordance with ISO 6892-1. The yield strength, ultimate tensile strength and elongation of the specimens treated vs not treated by hot isostatic pressing (HIP) (as shown in Table 1) were determined from the results of tensile testing.

For numerical modeling of the tensile specimens, the mechanical properties of homogeneous materials obtained from experimental data were set in the model.

The study was divided into stages. At the first stage, the average mechanical properties of homogeneous materials $A$ and $B$ were used (the average experimental curves for materials A and B are shown in Fig. 4).

Considering that a number of experiments were conducted for each homogeneous material and that the specimens have different properties, calibration calculations were required to adapt the model of the bilinear elastoplastic material. During adaption, the tangent modulus of the material was chosen according to the experimental data so that the discrepancy was no more than $10 \%$.

The mechanical properties of the materials obtained from the calibration of homogeneous specimens are given in Table 2. A comparison of the modeling results with the average experimental curves is shown in Fig. S1,S2 (Supplementary Material).

The deviations determined from the modeling of a homogeneous composite were as follows: the modulus of elasticity $\approx 9 \%$, the yield strength $\approx 2 \%$ and the ultimate tensile strength $\approx 7 \%$.

As the mechanical properties of graded materials are not spatially homogeneous, the second stage of the modeling involved the analysis of lengthwise varying material properties. To set the varying mechanical properties, we introduced a parameter, the random variation of which determines the lengthwise variation of mechanical properties from the average values (Table 3). The lengthwise property variation in the specified ranges was no more than $\pm 5 \%$, which corresponds to the deviation of the experimental data from the average values (Fig. S3, Supplementary Material).

For each of the specimens (A, B), five random property distributions were generated and numerically modeled.

Following a series of analyses, we obtained five stressstrain curves for each specimen (A, B), as well as average model-predicted curves (Fig. S4, S5, Supplementary Material). 


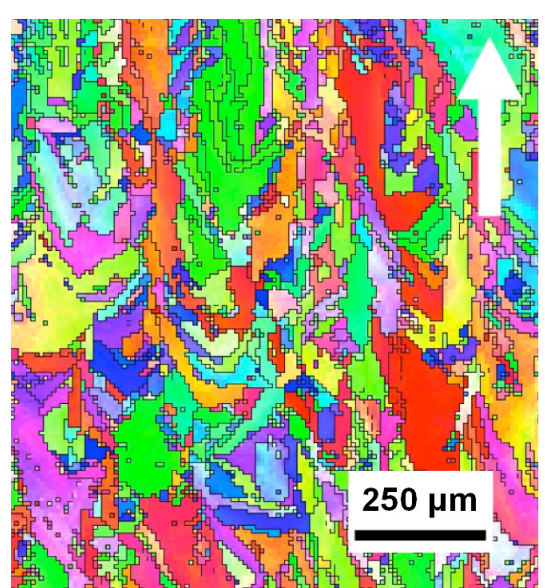

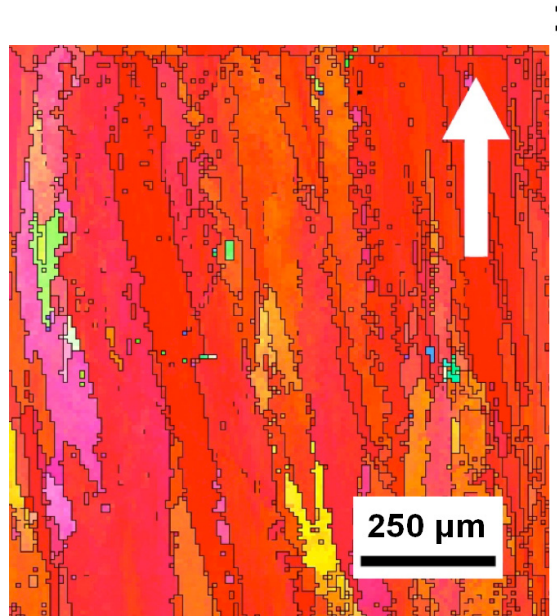

$\mathrm{b}$

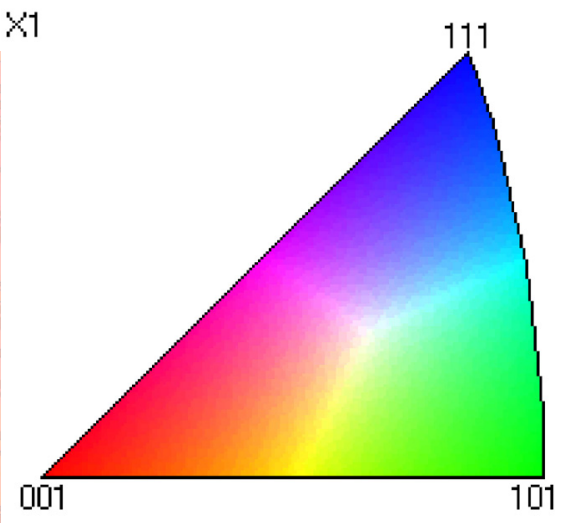

C

Fig.3. (Color online) EBSD analysis of the specimens manufactured by SLM: crystallographic orientation map for specimen A (a); crystallographic orientation map for specimen B (b); index map (c) for figures (a) and (b). The growth direction in the specimens is indicated by the arrow.

Table 1. The results of tensile testing of specimens of Inconel 718 alloy manufactured by SLM.

\begin{tabular}{|c|c|c|c|}
\hline Type of specimen & Yield strength $\sigma_{0.2}, \mathrm{MPa}$ & Ultimate strength $\sigma_{U^{\prime}} \mathrm{MPa}$ & Percent elongation $\delta, \%$ \\
\hline \multicolumn{3}{|c|}{ SLM } \\
\hline A & $650 \pm 11$ & $845 \pm 9$ & $31 \pm 6$ \\
\hline B & $543 \pm 2$ & $782 \pm 6$ & $38 \pm 1$ \\
\hline \multicolumn{5}{|c|}{ SLM + HIP } \\
\hline A & $645 \pm 6$ & $1025 \pm 14$ & $34 \pm 3$ \\
\hline
\end{tabular}

Table 2. The average mechanical properties of materials A and B in the mathematical model.

\begin{tabular}{|c|c|c|c|c|}
\hline Material & Young's Modulus $E, \mathrm{GPa}$ & Poisson's Ratio $\mu$ & Yield strength $\sigma_{0.2}, \mathrm{MPa}$ & Tangent Modulus $E_{t}, \mathrm{MPa}$ \\
\hline A & 71.5 & 0.3 & 645 & 2550 \\
\hline B & 67.4 & 0.3 & 477 & 2200 \\
\hline
\end{tabular}

In addition to the homogeneous specimens, we manufactured graded-structure specimens of the main material A and two inserts of the material B (Fig. 2). They were also subjected to tensile testing to determine their mechanical properties.

For comparison with the modeling results, we used the average experimental curve obtained from a series of experiments on the composite (Fig. 5).

During the experiment, we measured the strain fields of the specimen at different stages of elongation (Fig. S6, Supplementary Material). Comparison of modeling results for specimen $\mathrm{A}+\mathrm{B}$, made of homogeneous materials and materials with varying properties, with the average experimental curve is shown in Fig. 6.

For the composite with a random variation of mechanical properties in the range of $\pm 5 \%$ of the average values, the deviations were as follows: the modulus of elasticity $\approx 6 \%$, the yield strength $\approx 4 \%$ and the ultimate tensile strength $\approx 5 \%$.

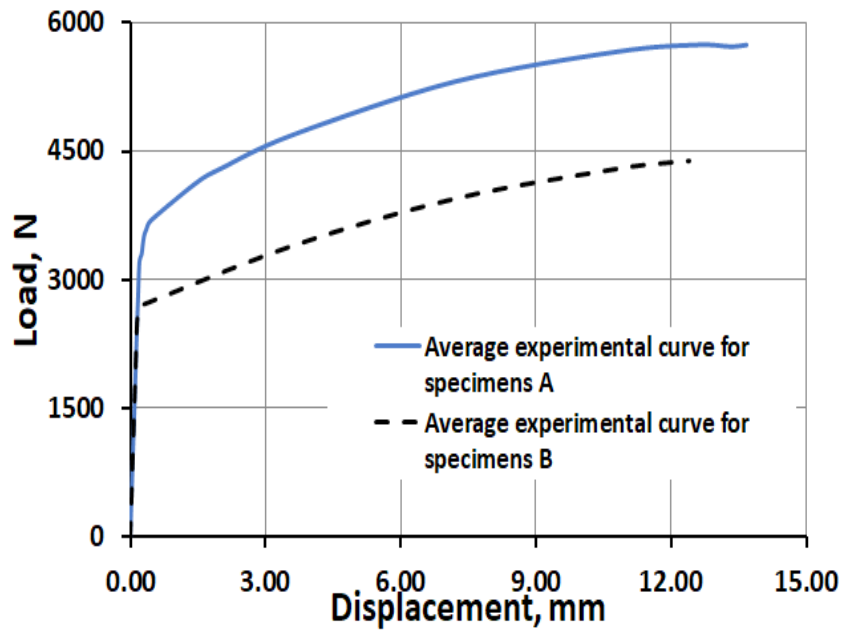

Fig. 4. The average experimental curves for specimens A and B. 
Table 3. Mechanical properties of graded materials A and B in the mathematical model.

\begin{tabular}{|c|c|c|c|c|}
\hline Material & Young's Modulus $E$, GPa & Poisson's Ratio $\mu$ & Yield strength $\sigma_{0.2,}$, MPa & Tangent Modulus, MPa \\
\hline A max & 75 & 0.3 & 677 & 2650 \\
\hline A min & 68 & 0.3 & 612 & 2550 \\
\hline B max & 72 & 0.3 & 500 & 2300 \\
\hline B min & 62 & 0.3 & 453 & 2200 \\
\hline
\end{tabular}

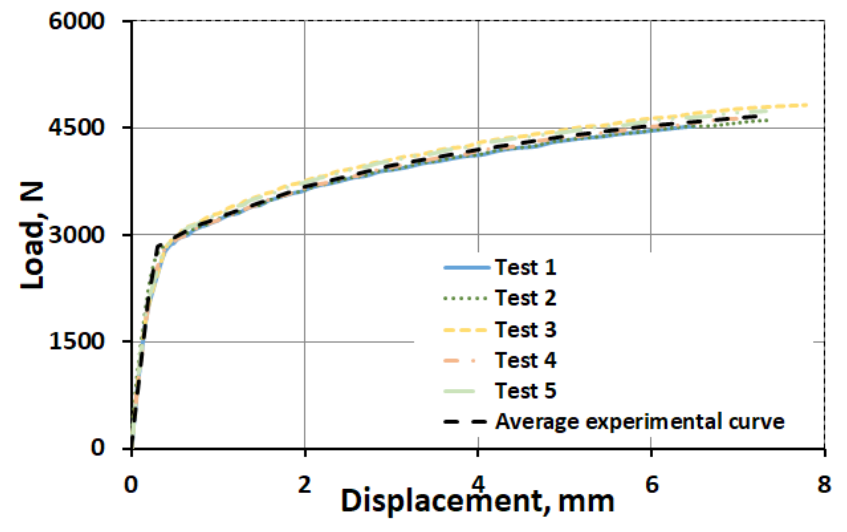

Fig. 5. (Color online) The average experimental curve for specimens $\mathrm{A}+\mathrm{B}$.

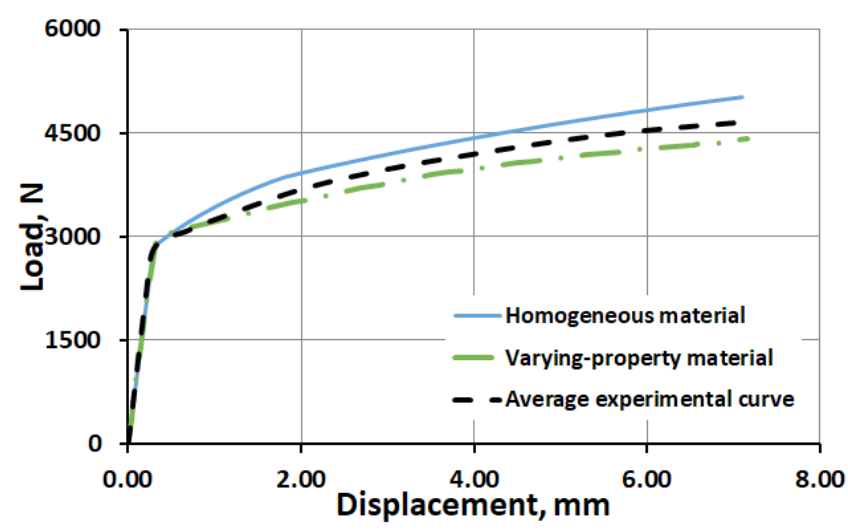

Fig. 6. (Color online) Comparison of the modeling results with the average experimental curve for specimens $\mathrm{A}+\mathrm{B}$.

\section{Conclusions}

This paper shows the development of a numerical approach to the modeling of tensile specimens manufactured from a functionally graded material. Specimens with various mechanical properties were modeled. The deviations obtained in the modeling of a homogeneous composite were as follows: the modulus of elasticity $\approx 9 \%$, the yield strength $\approx 2 \%$ and the ultimate tensile strength $\approx 7 \%$.

According to the modeling results, where a lengthwise random variation of mechanical properties is considered, the simplified results of numerical modeling correlate well with the experimental results. For the composite with a random variation of mechanical properties in the range of $\pm 5 \%$ of the average value, the deviations were as follows: the modulus of elasticity $\approx 6 \%$, the yield strength $\approx 4 \%$ and the ultimate tensile strength $\approx 5 \%$.

The bilinear elastoplastic model, however, is unpractical when it comes to measuring the tensile set.

One of the possible promising ways to develop the established approach minimizing deviations and ensuring a correlation with the experimental curve is the development and use of a multilinear plastic material model that more accurately describes the nature of material plasticity.

Acknowledgements. The work was carried out with the funding from the Federal Target Program «Research and Development in Priority Areas for the Development of the Russian Science and Technology Complex for 2014-2020». The unique identifier of the project RFMEFI57817X0245.

Supplementary Material. The online version of this paper contains supplementary material (figures) available free of charge at the journal's Web site (www.lettersonmaterials.com).

\section{References}

1. V.A. Popovich, E.V. Borisov, A.A. Popovich, V.Sh. Sufiiarov, D. V. Masaylo, L. Alzina. Materials Design. 114, 441 (2017). DOI: 10.1016/j.matdes.2016.10.075

2. A.A. Popovich, V.S. Sufiiarov, E.V. Borisov, I. A. Polozov, D.V. Masaylo, A.V. Grigoriev. Russian Journal of Non-Ferrous Metals. 58 (4), 389 (2017). DOI: $10.3103 /$ S1067821217040149

3. O. A. Peverini, M. Lumia, F. Calignano, D. Manfredi, G. Addamo, M. Lorusso, E. Ambrosio, G. Virone, P. Fino, R. Tascone. 201711th European Conference on Antennas and Propagation (EUCAP). 563 (2017). DOI: 10.23919/eucap.2017.7928301

4. V.S. Sufiiarov, A.A. Popovich, E.V. Borisov, I. A. Polozov. Tsvetnye Metally. 8, 76 (2015). DOI: $10.17580 /$ tsm.2015.08.11

5. A. Popovich, V.Sh. Sufiiarov, E. V. Borisov, I. A. Polozov. International Journal of Bioprinting. 2 (2), 187 (2016). DOI: $10.17580 / \mathrm{nfm} .2015 .01 .08$

6. Q. Jia, D. Gu. Optics \& Laser Technology. 62, 161. (2014). DOI: 10.1016/j.optlastec.2014.03.008

7. P.L. Blackwell. Journal of materials processing technology. $170 \quad(1-2), 240 \quad$ (2005). DOI: 10.1016/j.jmatprotec.2005.05.005 
8. A.A. Popovich, I. A. Polozov, E. V. Borisov. Key Engineering Materials. 651-653, 665. (2015). DOI: 10.4028/www.scientific.net/kem.651-653.665

9. V.S. Sufiiarov, A.A. Popovich, E.V. Borisov, I. A. Polozov. Tsvetnye Metally. 1, 81 (2016). DOI: $10.17580 /$ tsm.2016.01.14

10. V.A. Popovich, E. V. Borisov, V. Heurtebise, T. Riemslag, A. A. Popovich, V.Sh. Sufiiarov. In: TMS 2018 14th Annual Meeting \& Exhibition Supplemental Proceedings, ed. by The Minerals, Metals \& Materials Society, Springer, Cham. (2018), 85.

11. S. Suresh. Fundamentals of functionally graded materials: processing and thermomechanical behavior of graded metals and metal-ceramic composites. London. IOM Communications Ltd. (1998) $165 \mathrm{p}$.

12. T. Hirai. Materials Science and Technology a Comprehensive Treatment. 17B (2), 293 (1996).

13. Z.H. Jin, R.C. Batra. Journal of the Mechanics and Physics of Solids. 44 (8), 1221 (1996). DOI: 10.1016/0022-5096(96)00041-5

14. G. Anlas, M. H. Santare, J. Lambros. International Journal of Fracture. 104 (2), 131 (2000).

15. T. Fujimoto, N. Noda. Journal of the American

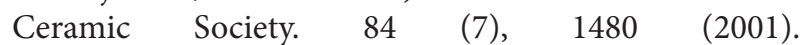
DOI: $10.1111 /$ j.1151-2916.2001.tb00864.x

16. ANSYS ${ }^{\circ}$ Mechanical APDL, Release 19, Help System, Mechanical APDL Theory Guide. ANSYS Inc. 